\title{
The use of opioids in the treatment of oncologic pain in the elderly
}

\author{
O uso de opioides no tratamento da dor oncológica em idosos
}

Ledismar José da Silva¹, Diego Machado Mendanha¹, Patrícia Pádua Gomes ${ }^{1}$

DOI 10.5935/2595-0118.20200014

\section{ABSTRACT}

BACKGROUND AND OBJECTIVES: The use of opioids in cancer is already widespread and proven by several well-controlled clinical trials. However, the elderly with cancer pain are=undertreated due to the lack of knowledge in the management of these patients, the underestimation of pain, as well as the fear of complications arising in this age group. Therefore, the scientific community contributes to giving inputs to create possible clinical and health guidelines. The present study aimed to perform a systematic literature review of opioid treatments proposed for cancer-related pain in elderly patients.

CONTENTS: The search on the literature included papers addressing cancer pain treatment with opioids among the elderly, published from 2008 to 2018, and available in Portuguese or English. Searches were conducted on Medical Literature, Analysis, and Retrieval System Online (MEDLINE) and Latin American and Caribbean Health Sciences Literature (LILACS) electronic databases using the keywords "cancer pain", "opioids", and "elderly" in both languages, combined with the Boolean operator "AND". To analyze the quality of the method, the adapted Critical Appraisal Skills Programme was used. Of a total of 411 studies found, 32 were included. About $75 \%$ of the selected articles were published in the last five years.

CONCLUSION: The results showed that opioids remain the pillar to treat cancer-related pain in the elderly. They can be used for better management of pain, but with caution due to the possible adverse effects. In addition, pain management in the elderly requires a multifactorial analysis, including comorbidities, polypharmacy, and patient functionality. Therefore, an individualized approach in the elderly patient is required in order to enhance results, reduce side effects, and improve quality of life. Keywords: Cancer pain, Elderly, Opioids.

Ledismar José da Silva - Dhttps://orcid.org/0000-0002-3551-2650;

Diego Machado Mendanha - Dhttps://orcid.org/0000-0003-1683-2429;

Patrícia Pádua Gomes - Dhttps://orcid.org/0000-0003-1726-0063.

1. Pontifícia Universidade Católica de Goiás, Departamento de Medicina, Goiânia, GO, Brasil.

Submitted on June 23, 2019.

Accepted for publication on December 10, 2019.

Conflict of interests: none - Sponsoring sources: none.

Correspondence to:

Ledismar José da Silva

Avenida Universitária, 1440 - Setor Universitário

74605-010 Goiânia, GO, Brasil.

E-mail: ledismarsilva@gmail.com

(C) Sociedade Brasileira para o Estudo da Dor

\section{RESUMO}

JUSTIFICATIVA E OBJETIVOS: O uso de opioides em dor oncológica já é amplamente difundido e comprovado por diversos ensaios clínicos bem controlados. Entretanto, os idosos com dor oncológica são subtratados pela falta de conhecimento no manejo, a não valorização álgica nesses pacientes, bem como o receio das complicaçóes advindas nesse grupo etário. Portanto, contribui a comunidade científica, dando substrato para a elaboração de possíveis diretrizes clínicas e de saúde. Este estudo teve como objetivo realizar uma revisão sistemática da literatura sobre o tratamento farmacológico com opioides proposto para dor oncológica em pacientes idosos.

CONTEÚDO: A busca na literatura incluiu artigos sobre o uso de opioides para o tratamento da dor oncológica em idosos, publicados entre 2008 e 2018, disponíveis em português ou inglês. Foram conduzidas buscas nas bases eletrônicas de dados Medical Literature, Analysis, and Retrieval System Online (MEDLINE) and Latin American and Caribbean Health Sciences Literature (LILACS) utilizando os descritores "dor oncológica", "opioides" e "idoso" em ambas as línguas, combinados com o operador booleano "AND". Para a análise da qualidade metodológica, foi utilizado o Critical Appraisal Skills Programme adaptado. Do total de 411 estudos resultantes, foram incluídos 32 . Cerca de $75 \%$ dos artigos selecionados foram publicados nos últimos cinco anos.

CONCLUSÃO: Os resultados demonstraram que os opioides continuam sendo o pilar no tratamento da dor oncológica em idosos. Podem ser usados para o melhor gerenciamento da dor, mas com cautela por causa dos possíveis efeitos adversos. Além disso, o manejo da dor em idosos requer uma análise multifatorial incluindo as comorbidades, a polifarmácia e a funcionalidade do paciente. Portanto, é necessário tratar de modo individualizado o paciente idoso com o intuito de maximizar os resultados, diminuir os efeitos adversos e melhorar a qualidade de vida.

Descritores: Dor oncológica, Idosos, Opioides.

\section{INTRODUCTION}

Aging is a worldwide phenomenon. Over the next 43 years, the number of people over 60 will be three times higher than the current one ${ }^{1}$. The elderly population in Brazil has also been growing exponentially. By 2030 there will be 41.5 million older people or $18 \%$ of the population ${ }^{2}$. Due to this, population aging has been one of the major public health challenges, because as people get older, they are more likely to develop or contract chronic diseases such as cancer, as risk factors accumulate for certain types of this disease ${ }^{3}$. Currently, more than $70 \%$ of cancer cases worldwide occur in 
the elderly ${ }^{4}$. Therefore, there is an increase in the prevalence of chronic health problems and disabilities associated with the population of this age group, involving important specificities such as multimorbidities, polypharmacy, and their complications ${ }^{3}$.

In elderly cancer patients, pain is the most prevalent symptom, as about $80 \%$ of them report some kind of painful sensation. Inadequate pain treatment can have serious consequences, both individually and socially ${ }^{5-8}$.

Pain management should be performed according to the three-step analgesic ladder proposed by the World Health Organization (WHO) in the $1980 \mathrm{~s}^{9}$, in which opioids are recommended for the treatment of moderate to severe pain ${ }^{8,10}$. In addition to limited evidence for opioid use in elderly patients, there are still barriers such as fears, myths, and stigmas regarding this type of prescription ${ }^{5,10-12}$.

Therefore, this study aimed to conduct a systematic literature review addressing the use of opioids in the treatment of cancer pain in the elderly. The study also aimed to explore the repercussions of opioid use in pain treatment, as well as its main barriers to adequate management in this population.

\section{CONTENTS}

This study was conducted as a systematic literature review following the guidelines established by Preferred Reporting Items for Systematic Reviews and Meta-analyzes (PRISMA). In order to achieve a systematic literature review, the research question was initially established considering the proposed theme, i.e., the use of opioids in cancer pain treatment in the elderly, thus classifying individuals over 60 years. Then, between March and December 2018, searches were done in the Medical Literature, Analysis, and Retrieval System Online (MEDLINE) and Latin American and Caribbean Health Sciences Literature (LILACS) electronic databases, aiming at gathering and evaluating the main articles on the use of opioids for cancer pain treatment in the elderly, published between
2008 and 2018, available in Portuguese or English, using the descriptors "cancer pain," "opioids", and "elderly" and their respective Portuguese terms, all present in the Health Science Descriptors (DeCS) and Medical Subject Headings (MeSH), combined with the Boolean operator "AND".

The criteria used for articles inclusion were: a) articles concerning the proposed theme, i.e., the use of opioids in cancer pain treatment in the elderly; b) articles published between 2008 and 2018; c) articles in Portuguese or English; d) articles available in full; e) articles on randomized studies, systematic reviews and observational studies; f) articles that met the criteria proposed by the Critical Appraisal Skills Program (CASP) checklist for qualitative research.

Exclusion criteria were a) articles addressing a non-pharmacological treatment of pain; b) articles describing animal studies; c) dissertations, theses and case reports; d) repeated articles among electronic databases.

The articles were categorized, allowing the gathering of information such as identification of the original article and its authors, journal, year of publication, database, methodological characteristics, level of evidence, measured interventions, and results found. The critical analysis of the data obtained in the studies was performed after the organization of the selected articles. The CASP instrument was applied to ensure the methodological rigor, relevance and credibility necessary for an integrative review of studies with different approaches.

Searches in the MEDLINE and LILACS electronic databases resulted in 411 articles published between 2008 and 2018 . The initial evaluation was performed by reading the title, excluding 321 articles that did not present the theme "opioids in cancer pain treatment in the elderly". Then, the remaining 90 articles with inclusion potential were previously selected for evaluation of their abstracts according to the eligibility criteria. Three independent reviewers read the abstracts, and the publications that met the inclusion criteria were then fully assessed. In total, 32 articles were selected for this study; $75 \%$ were published in the last five years (Figure 1, Table 1).

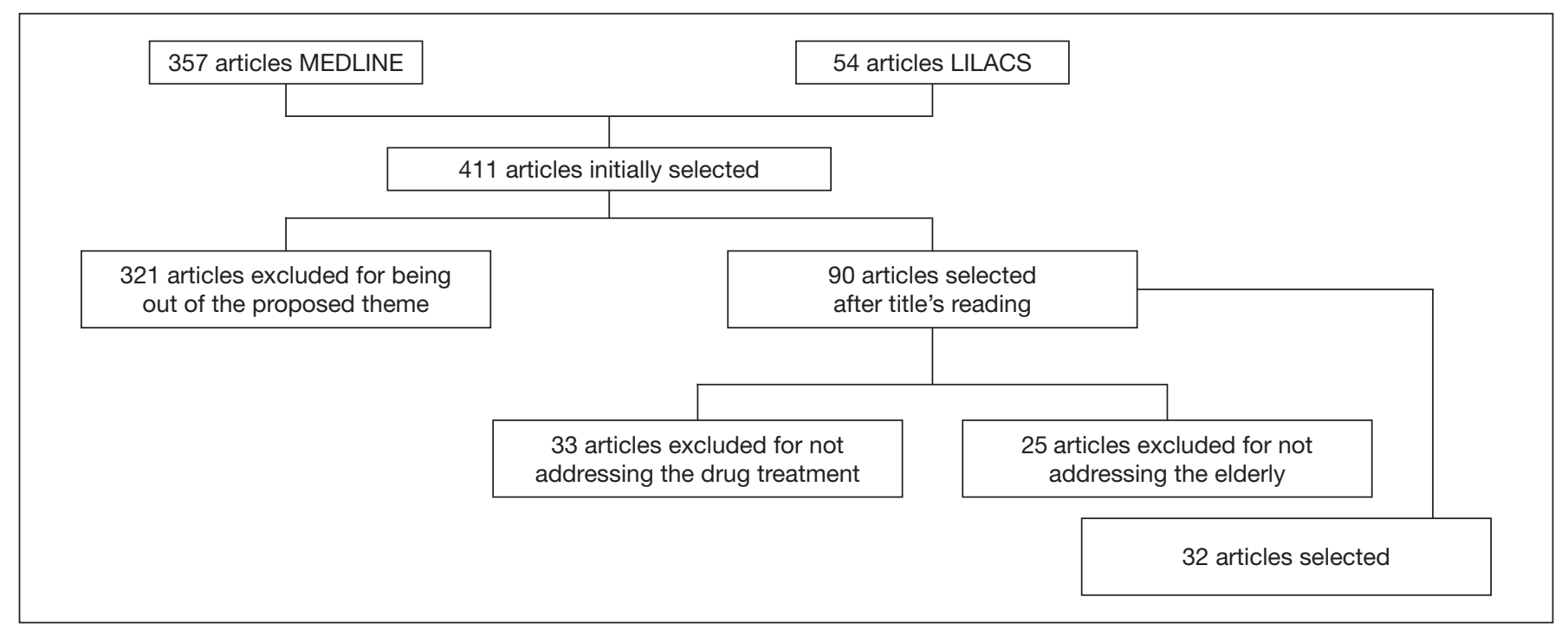

Figure 1. Data collection 
Table 1. Selected articles

\begin{tabular}{|c|c|c|c|c|}
\hline Authors & Purpose & Methodology & Therapy & Conclusion \\
\hline Passik $^{13}$ & $\begin{array}{l}\text { Assess long-term opioid the- } \\
\text { rapy, including unmet needs, } \\
\text { risks, and solutions }\end{array}$ & Literature review & Opioids & $\begin{array}{l}\text { Chronic pain and abuse of prescribed } \\
\text { opioids are common and substantially affect } \\
\text { patients, doctors, and the society. Aggressi- } \\
\text { ve treatment of chronic pain should be ba- } \\
\text { lanced with the need to minimize the risks of } \\
\text { opioid abuse, misuse, and deviation. }\end{array}$ \\
\hline
\end{tabular}

Wilson et al. ${ }^{11}$ Examine the prevalence of Multicenter study pain, its perceived severity, addressing cancer and its correlation across patients' pain and a range of physical, social, assessing 21 other psychological, and existential symptoms and consymptoms.

cerns

Paice and Review available pain manaFerrell ${ }^{8} \quad$ gement treatments considering the individual needs of patients as well as special populations, including the elderly, cancer survivors, patients with addictive diseases, and those at the end of life.

Rangel and Telles $^{5}$

HennemannKrause $^{14}$

$\begin{array}{ll}\text { Madadi et } & \text { Identify patterns and charac- } \\ \text { al. }{ }^{15} & \text { teristics among opioid users }\end{array}$

$\begin{array}{ll}\text { Madadi et } & \text { Identify patterns and charac- } \\ \text { al. }^{15} & \text { teristics among opioid users }\end{array}$

Address the principles for cancer pain treatment, as well as barriers related to patients, health professionals, and the health system.

Present the rational use of Literature review analgesic drugs, highlighting their indications, doses, adverse effects, and proper care for the adequate prescription of common analgesics and opioids for the control of chronic cancer pain.

Srisawang et Assess the knowledge and al. ${ }^{16} \quad$ attitudes of physicians and

Zeppetella $^{17} \quad$ Known non-parenteral opioid

Kraychete, Siqueira and Garcia $^{18}$
Literature review

Common anal- Opioids prescription should not be done begesic drugs cause the patient has a fatal disease, but acand opioids cording to the intensity of the pain. teristics among opioid users policymakers/regulators regarding the use of opioids for cancer pain management. formulations, such as sublingual fentanyl, which can provide faster and more effective relief from transitory exacerbation cancer pain.

Qualitative study Opioids

Cross-sectional study Opioids

Systematic review

Non-paren- Fentanyl formulation available at doses of teral opioids, $100,200,400,600$ and $800 \mu g$ approved for such as the treatment of transitory exacerbation pain sublingual fen- in opioid therapy tolerant adult cancer patanyl tients for underlying persistent cancer pain

Opioids

New susceptible groups of opioid users with related cause of death were identified. The first evidence to help quantify the contribution of opioid misuse to user mortality in Canada

Continued education for physicians and conference organization is required for policymakers/regulators. Special education and training should be addressed to clarify the training should be addressed

Discuss recommendations for Systematic review opioid use in newborns, children and the elderly
The use of opioids at extreme ages is still a challenge. However, continued education around the subject is needed, stimulating clinical research and the creation of evidence-based recommendations. The safe use of these agents in the correct indication and proportion for pain relief decreases risks and should be the basis of sound clinical conduct. 
Table 1. Selected articles - continuation

\begin{tabular}{|c|c|c|c|c|}
\hline Authors & Purpose & Methodology & Therapy & Conclusion \\
\hline $\begin{array}{l}\text { Nunes, } \\
\text { Garcia and } \\
\text { Sakata }^{19}\end{array}$ & $\begin{array}{l}\text { Assess the use of morphine } \\
\text { as the first drug for moderate } \\
\text { cancer pain treatment in pa- } \\
\text { tients with advanced disease } \\
\text { and/or metastasis, as an op- } \\
\text { tion to the recommendations }\end{array}$ & $\begin{array}{l}\text { Randomized control- } \\
\text { led study }\end{array}$ & Morphine & $\begin{array}{l}\text { The use of morphine as the first drug for pain } \\
\text { treatment did not promote a better analgesic } \\
\text { effect than the WHO-recommended ladder, } \\
\text { and there was a higher incidence of adverse } \\
\text { effects. }\end{array}$ \\
\hline
\end{tabular}
of the WHO-recommended analgesic ladder.

Rocha et al..$^{20}$ Analyze the self-care of older people living with cancer in outpatient treatment, from the perspective of their autonomy

Kim et al. ${ }^{21}$ Assess pain response to opioid rotation or opioid combination in patients with uncontrolled cancer pain

Reticena, Reticena, Understand the experiences
Beuter and of the elderly with cancer pain Sales ${ }^{22}$

Reyes-Gibby, Anderson and Todd 6

Determine the risk of opioid misuse among emergency services for cancer pain patients and assess the demographic and clinical factors associated with increased risk of opioid abuse.

Coluzzi et Review some basic principles al. ${ }^{10}$ of opioid analgesia based on experience and knowledge of current publications on this care

GaliciaCastillo $^{12}$

Manage chronic pain safely in the elderly

Cella et al. ${ }^{23}$ Assess the prevalence of pain and opiophobia in cancer patients.

Lin et al. ${ }^{24}$

Examine Taiwan's opioid prescribing standards for cancer patients to discover their potential concerns

Oosten et al. ${ }^{25}$

Study the pharmacokinetics of subcutaneous and transdermal fentanyl and assess relays between subcutaneous and transdermal uses

Reddy et al. ${ }^{26}$ Determine the relationship Retrospective study between the equivalent daily dose of morphine and the dose of transdermal fentanyl in opioid rotation
Qualitative and descriptive research

Randomized study

Opioids

Qualitative research based on Heidegger's phenomenology, with recorded interviews

A cross-sectional stu- Opioids

dy with a convenience sample

Literature review

Opioids

A cross-sectional Opioids study with patients undergoing exclusive cancer clinical treatment in an outpatient cancer hospital

Review of claims in Opioids the Taiwan National Health Insurance database for cancer-diagnosed patients from 2003 to 2011

Cohort study transdermal fentanyl
The autonomy for self-care of the elderly is manifested in the concern with food, knowledge of the body's limits, changes imposed by living with cancer, and family support.

For patients with chronic uncontrolled cancer pain, both opioid rotation and combination strategies appear to provide significant pain relief and better patient satisfaction.

Cancer pain has biopsychosocial repercussions for the elderly, generating changes in their life activities and requiring holistic and authentic care.

The risk of opioid misuse among cancer patients is substantial. Tracking misuse in emergency departments is feasible

Establish titration, individualization, and gradual reduction, along with the application of other good medical practice and clinical experience/judgment, including non-pharmacological approaches, can assist health care professionals in the effort to achieve optimal pain treatment.

A complete assessment, including description and management of pain, comorbidities, physical examination, and diagnostic tests are required for patient control. It is also important to inquire about the history of substance abuse.

A high prevalence of moderate to severe pain was found in the observed patients, as well as a high prevalence of opiophobia.

The use of strong short-acting opioids increased during the study period. Instead of oral opioids, transdermal fentanyl was the most commonly used opioid among cancer patients in Taiwan.

Subcutaneous Absorption may lead to fluctuations in plasand transder- ma transdermal and subcutaneous fentanyl mal fentanyl concentrations. Relay schemes are not applicable for subcutaneous and transdermal fentanyl rotations

Morphine and The median rotation rate of transdermal fentanyl for the equivalent daily morphine dose was $100 \mathrm{mg} /$ day and $2.4 \mu \mathrm{g} / \mathrm{h}$, suggesting that $100 \mu \mathrm{g} / \mathrm{h}$ is equivalent to the $240 \mathrm{mg}$ daily morphine dose. 
Table 1. Selected articles - continuation

\begin{tabular}{|c|c|c|c|c|}
\hline Authors & Purpose & Methodology & Therapy & Conclusion \\
\hline $\begin{array}{l}\text { Barbera et } \\
\text { al. }{ }^{27}\end{array}$ & $\begin{array}{l}\text { Verify whether opioid pres- } \\
\text { criptions changed among ol- } \\
\text { der adults after 2007, in the } \\
\text { context of changing opioid re- } \\
\text { gulations, and whether effects } \\
\text { were different among patients }\end{array}$ & $\begin{array}{l}\text { Elderly patients strati- } \\
\text { fied annually into three } \\
\text { groups: no history of } \\
\text { cancer, diagnosed with } \\
\text { cancer for more than } \\
5 \text { years and diagno- }\end{array}$ & Opioids & $\begin{array}{l}\text { Decreasing prescription rates have been ob- } \\
\text { served in some drug subclasses. The poten- } \\
\text { tial impact of these changes on the quality of } \\
\text { symptom control for cancer patients requires } \\
\text { further investigation. }\end{array}$ \\
\hline
\end{tabular}
with a history of cancer sed with cancer for 5 years or less. Trends over time have been assessed per year for 1) opioid prescription rate, comparing trends before and after 2007; 2) average daily dose of opioid

Bennett, Paice and Wallace $^{28}$

Understand the comprehensive management of cancer pain, including a thorough assessment, along with the use of pharmacological, non-pharmacological, integrative, and interventional therapies.

Haider et al. ${ }^{29}$ Assess changes in the opioid type and prescription dose among patients who are referred by oncologists to an outpatient palliative care clinic

Kuip et al. ${ }^{30}$ Summarize the multiple factors studied that potentially influence fentanyl pharmacokinetics focusing on implications for cancer patients

Lee et al. ${ }^{31}$ Assess the non-inferiority of oxycodone/naloxone compared to controlled-release oxycodone for cancer pain control

Nosek et al. ${ }^{32}$ Compare analgesia and adverse effects during oral administration of morphine and oxycodone, transdermal fentanyl and buprenorphine in cancer and pain patients

SchmidtHansen et al. ${ }^{33}$

Assess the efficacy and tolerability of oxycodone in any pain administration route in adults with cancer.

Yen et al. ${ }^{7} \quad$ Assess the efficacy and safety of proportional doses of fentanyl oral soluble film in patients with transitory exacerbation cancer pain.

\section{Literature review}

Review of electronic patient health records at new CP Outpatient Consultations between January 1 and April 30 of each year from 2010 to 2015. Demographic data, cancer type, and stage, symptom assessment, performance status, opioid data were collected.

Opioid type and dose defined as the equivalent daily dose of morphine

\section{Systematic review}

Fentanyl

Pharmacological, non- pharmacological, integrative, and interventional therapies

Opioids

Fentanyl

Randomized, open, phase IV, parallel-group clinical trial

Randomized clinical trial

transdermal
fentanyl, and
buprenorphine

Systematic literature Oxycodone review

An open, non-com- Fentanyl oral parative multicenter soluble film study
Although cancer pain remains prevalent, it remains undertreated, partly due to the concerns about opioid use. Opioids' efficacy in advanced disease is already clearly established; however, there are still issues about opioids' safety and efficacy in long-term cancer survivors.

Over the past few years, the equivalent daily dose of morphine prescribed by reference oncologists has decreased. Following hydrocodone reclassification, the use of tramadol with less stringent prescription limit increased
Oxycodone/ oxycodone

Morphine, All opioids were effective and well-tolerated. oxycodone, Morphine was the most effective for pain imbuprenorphine tionnaire items regarding the negative impact of pain on patients' daily activities.

For clinical purposes, oxycodone or morphine may be used as first-line oral opioids for pain relief in cancer adults.

The dose of fentanyl oral soluble film proportional to the opioid regimen for basal pain treatment is effective and well-tolerated for the treatment of patients with transitory exacerbation cancer pain. 
Table 1. Selected articles - continuation

\begin{tabular}{|c|c|c|c|c|}
\hline Authors & Purpose & Methodology & Therapy & Conclusion \\
\hline $\begin{array}{l}\text { Guitart et } \\
\text { al. }{ }^{34}\end{array}$ & $\begin{array}{l}\text { Assess the effect of sublin- } \\
\text { gual fentanyl tablets for pain } \\
\text { relief, quality of life and ad- } \\
\text { verse effects in cancer pain } \\
\text { patients according to cancer } \\
\text { stage and basal opioid regi- } \\
\text { men }\end{array}$ & Qualitative study & $\begin{array}{l}\text { Sublingual } \\
\text { fentanyl ta- } \\
\text { blets }\end{array}$ & $\begin{array}{l}\text { Subgroup exploratory analyses demonstrate } \\
\text { the efficacy and safety of sublingual fentanyl } \\
\text { tablets for treating transitory exacerbation } \\
\text { cancer pain, regardless of cancer stage and } \\
\text { basal opioid regimen. }\end{array}$ \\
\hline Masel et al. ${ }^{35}$ & $\begin{array}{l}\text { Document the feasibility of } \\
\text { fentanyl oral tablets for the } \\
\text { treatment of patients with } \\
\text { transitory exacerbation can- } \\
\text { cer pain. }\end{array}$ & Prospective study & $\begin{array}{l}\text { Fentanyl oral } \\
\text { tablets }\end{array}$ & $\begin{array}{l}\text { Treatment with fentanyl oral tablets led to } \\
\text { quick pain relief and reductions in the num- } \\
\text { ber of episodes of transitory exacerbation } \\
\text { cancer pain. Patient satisfaction was rated } \\
\text { as excellent or good. }\end{array}$ \\
\hline Peng et al. ${ }^{36}$ & $\begin{array}{l}\text { Compare the efficacy and ad- } \\
\text { verse effects of patient-con- } \\
\text { trolled intravenous analgesia } \\
\text { with hydromorphone, sufen- } \\
\text { tanil, and oxycodone in the } \\
\text { treatment of patients with ad- } \\
\text { vanced cancer and pain. }\end{array}$ & $\begin{array}{l}\text { Retrospective serial } \\
\text { study }\end{array}$ & $\begin{array}{l}\text { Patient-con- } \\
\text { trolled intra- } \\
\text { venous hydro- } \\
\text { morp h on e, } \\
\text { sufentanil, and } \\
\text { oxycodone }\end{array}$ & $\begin{array}{l}\text { There was no significant difference in analge- } \\
\text { sic effect and adverse effect between hydro- } \\
\text { morphone, sufentanil, and oxycodone. }\end{array}$ \\
\hline $\begin{array}{l}\text { Yamada et } \\
\text { al. } .^{37}\end{array}$ & $\begin{array}{l}\text { Assess the effect of con- } \\
\text { tinuous pain management } \\
\text { interventions and opioid-in- } \\
\text { duced adverse effects on ou- } \\
\text { tpatients with cancer }\end{array}$ & Systematic review & Opioids & $\begin{array}{l}\text { Pharmacist interventions can help to ade- } \\
\text { quately achieve the management of pain } \\
\text { and adverse effects through interviews and } \\
\text { ongoing assessments of cancer patients } \\
\text { prior to consultations with physicians, whi- } \\
\text { ch underlines the importance of pharmacist } \\
\text { interventions. }\end{array}$ \\
\hline
\end{tabular}

\section{DISCUSSION}

The aging process is one of the factors that leads to the increased incidence of cancer, as there are inherent physiological changes that jointly cause molecular changes. These changes are combined with mitogenic factors that, associated with the insufficiency and dysregulation of the immune system that is characteristic of this age group, favor cell proliferation and, consequently, the onset of cancer ${ }^{38}$.

The physiological changes caused by aging also significantly affect the metabolism of administered drugs, especially opioids. Thus, healthcare professionals should be aware of the following factors: patient susceptibility to adverse drug effects, iatrogenic cascade, adverse drug reactions, hospitalization, and institutionalization, as well as polypharmacy commonly found in the practical reality of the elderly.

Usually, as a result of aging, organs and systems have less functional reserve. Therefore, they present particularities involving the pharmacokinetics and pharmacodynamics of drugs regarding absorption, distribution, metabolism and excretion variables (Table 2 ).

Pain is an unpleasant experience associated with tissue or potential injury, with sensory, emotional, cognitive, and social components. In turn, persistent pain is more complicated in

Table 2. Pharmacological changes due to aging

\begin{tabular}{|c|c|}
\hline Absorption & Distribution \\
\hline $\begin{array}{l}\text { Reduction of: } \\
\text { - Splanchnic blood flow } \\
\text { - Gastric secretion } \\
\text { - Absorption surface } \\
\text { - Gastrointestinal motility } \\
\text { Increased gastrointestinal pH }\end{array}$ & $\begin{array}{l}\text { Reduction of: } \\
\text { - Plasma volume (8\%) } \\
\text { - Cardiac output } \\
\text { - Body water }(25 \%) \\
\text { - Plasma albumin }(20 \%) \\
\text { - Replacement of muscle mass with fat (30 to } 40 \%) \\
\text { Increased gastrointestinal pH }\end{array}$ \\
\hline Metabolism & Excretion \\
\hline $\begin{array}{l}\text { Reduction of: } \\
\text { - Liver mass } \\
\text { - Hepatic blood flow (40\%) } \\
\text { Change in enzymatic activity (cytochrome P450) } \\
\text { Change in phase I of metabolism (hydroxylation, oxidation, } \\
\text { hydrolysis, and n-demethylation) }\end{array}$ & $\begin{array}{l}\text { Reduction of: } \\
\text { - Kidney mass } \\
\text { - Number of functional nephrons } \\
\text { - Renal blood flow ( } 1-2 \% \text { per year, reaching } 50 \% \text { in old age) } \\
\text { - Glomerular filtration ( } 30 \text { to } 50 \%) \\
\text { Increased incidence of spontaneous glomerular sclerosis }\end{array}$ \\
\hline
\end{tabular}


the elderly than in younger patients. Up to $40 \%$ of elderly outpatients report pain, and this symptom affects $70-80 \%$ of patients with advanced cancer 5 .

For cancer pain treatment, it is necessary to know its classification. Didactically, pain can be divided into two main types: 1) nociceptive, which represents tissue damage; 2) neuropathic due to nervous system's injury or dysfunction as a result of abnormal activation of the nociceptive route. Also included in this analysis are the local effects of tumor growth and local invasion, as well as the effects of auxiliary therapies such as chemotherapy and radiotherapy, as well as other complications. Therefore, in cancer patients, mixed pain prevails ${ }^{5,38}$. Pain complaints can be both precursors for cancer diagnosis as a consequence of the treatment adopted. Most of the time, pain is identified by the patient him/herself and not by health care professionals.

It is noteworthy that not only cancer involvement, but also the aging process lead to limitations in the body's physiological functions. Thus, the elderly are more predisposed to dependence on other individuals for self-care, loss of autonomy, and deterioration of quality of life. In this environment, as the evaluation of painful conditions in the elderly is a multidimensional experience, it encompasses several domains, including sensory, cognitive, affective, behavioral and sociocultural ones. Given this, the importance of pain management using validated protocols and scales is evidenced in order to provide the most appropriate treatment according to the patients' individual particularities ${ }^{5,39}$.

However, there is not yet a single and exclusive standard instrument for the elderly that allows for global pain assessment and is free of bias and measurement errors, as there are different variables involved, such as patient interpretations of pain, expectations regarding the problem and its treatment. Notably, good anamnesis, detailed physical examination, and analysis of external factors are fundamental for the adoption of appropriate conduct.

From a general perspective, the $\mathrm{WHO}^{9}$ analgesic ladder is the most widely used. In specialized services, one-dimensional scales such as face and verbal numeric scales are employed, as well as multidimensional scales such as Geriatric Pain Measure
(GPM), McGill Pain Questionnaire (MPQ), Pain Assessment Checklist for Seniors with Limited Ability to Communicate (PACSLAC), and Pain Assessment in Advanced Dementia (PAINAID) ${ }^{38}$.

Cancer pain can be controlled with simple treatments in more than $80 \%$ of cases. In the other $20 \%$, however, it is necessary to adopt a multidisciplinary approach, with a careful reassessment of pain and the use of auxiliary drugs and/or non-pharmacological interventions for its control5 ${ }^{5,38}$. Regarding pharmacological treatment, opioids are among the most powerful and widely available drugs, constituting the pillar for the treatment of moderate to severe cancer pain ${ }^{7,12,19}$.

Recent clinical guidelines and recommendations on the management of patients with advanced cancer emphasize the importance of adequate pain relief with the use of opioid analgesics to improve their quality of life. It is essential that patients are continuously informed about the goals of pharmacological therapy and regularly reevaluated during treatment ${ }^{7}$.

The American Geriatrics Society has come to consider the use of opioids as an effective and sometimes indispensable option for treating pain in elderly patients. This is due, among other factors, to the potentially serious adverse events associated with the use of anti-inflammatory drugs, such as diclofenac and ibuprofen and COX-2 inhibitors (COXIB), such as celecoxib ${ }^{12}$. Opioids mimic the action of endogenous opioid peptides. They may suppress the activation of presynaptic and postsynaptic tension-dependent calcium channels or activate post-synapse potassium channels. This suppression results in decreased excitability and suppression of neuron activity-dependent transmitter release or adenylyl cyclase action, reducing the impulses to the brain and spinal cord ${ }^{12,14}$.

The four major opioid receptor subtypes are mu-opioid receptor (MOP), delta-opioid receptor (DOP), kappa opioid receptor (KOP), and nociceptin peptide factor (NOP). Clinically used opioids are mostly MOP selective, although they may also interact with other receptors if administered at high doses $^{14}$. Indeed, elderly cancer patients suffering from severe pain may benefit from the use of strong opioids such as fentanyl, morphine, oxycodone, hydromorphone, methadone, buprenorphine, among others (Table 3 ).

Table 3. Opioid analgesics

\begin{tabular}{|c|c|c|c|}
\hline Drugs & Presentation, doses & Therapeutic doses/interval & $\begin{array}{l}\text { Effects } \\
\text { (start/peak/end) }\end{array}$ \\
\hline Fentanyl & Patches 5,10 and $20 \mathrm{mg}$ & $5-20 \mathrm{mg} / 7$ days & 24 hours/72 hours \\
\hline Morphine LC & Capsules, 30, 60 and $100 \mathrm{mg}$ & $30-100 \mathrm{mg} / 8$ to 12 hours & 1 hour $/ 6$ hours $/ 14$ hours \\
\hline Hydromorphone & Extended release tablet, 8,16 and $32 \mathrm{mg}$ & $8-32 \mathrm{mg} / 24$ hours & 6 to 8 hours $/ 24$ hours \\
\hline Methadone & $\begin{array}{l}\text { Capsules, } 5 \text { and } 10 \mathrm{mg} \\
\text { Ampoules, } 10 \mathrm{mg} / \mathrm{mL}\end{array}$ & $10-50 \mathrm{mg} / 6$ to 12 hours & 1 hour/12 hours/25 hours \\
\hline Buprenorphine & Patches, 5,10 and $20 \mu \mathrm{g}$ & $5-20 \mu \mathrm{g} / 7$ days & 18 to 24 hours/72 hours/7 days \\
\hline
\end{tabular}

Source: Adapted from the Brazilian Society of Geriatrics and Gerontology ${ }^{38}$. 


\section{Fentanyl}

Transdermal fentanyl is a potent, long half-life agonist opioid with lipophilicity. It is very suitable for patients unable to use the oral route due to odynophagia and/or dysphagia, with persistent nausea and vomiting, in situations that may lead to bronchoaspiration, intolerance to morphine and other opioids, and due to its ease of use. Its use is recommended in patients with constant pain but little episodic pain. After the patch placement, effective analgesia start lasts 12 to 24 hours. The action time of each patch is 72 hours, remaining for 12 to 18 hours after its removal. The transmucosal formulation has short action duration, non-invasive administration route, and tolerable safety profile $e^{14,17,25,26,34,35}$.

\section{Morphine}

Morphine is indicated for pain classified as moderate to severe, with good results in pain of nociceptive or somatic origin, as $85 \%$ of them respond to this drug. It has a potent analgesic effect, short half-life, with therapeutic analgesia interval of 4 to 6 hours, without ceiling and linear effect, i.e., the higher the dose, the greater the analgesia. It is well-absorbed by the gastrointestinal tract, with action onset within 20 to $40 \mathrm{~min}$. It undergoes hepatic metabolism and renal elimination, and only a small part is eliminated by the gallbladder. It does not generally accumulate in tissues and the free fraction in plasma is dialyzable. However, in patients with impaired renal function, it has a stronger effect and longer action duration, because there is an accumulation of active metabolites, especially morphine-6-glucuronide 6,14,19,29,32,39.

\section{Oxycodone}

Oxycodone is a MOP agonist in the brain and spinal cord and has some activity in KOP. It goes through the first-pass metabo$\operatorname{lism}^{26}$. It is the preferred drug for change when morphine fails to provide effective pain relief but may also be recommended as a first-line drug for severe cancer pain control ${ }^{14,31}$.

\section{Hydromorphone}

Hydromorphone hydrochloride is intended for single-dose administration. It is a potent MOP agonist, showing a poor affinity for KOP. It is the only opioid that has controlled single-phase release and promotes continuous dose-dependent analgesia during the 24 hours interval between two doses. It is moderately water-soluble, has hepatic metabolism and urinary excretion. Its primary metabolite is hydromorphone-3-glucuronide (H3G), in which concentrations are approximately 27-times higher than those of the original drug, indicating that $\mathrm{H} 3 \mathrm{G}$ has a smaller volume of distribution and/or lower clearance ${ }^{7,14}$.

\section{Methadone}

The methadone is a synthetic opioid, agonist of MOP, KOP, DOP, and N-methyl D-Aspartate (NMDA) receptor. It appears to block serotonin and norepinephrine reuptake. It is a lipophilic drug, which analgesic effect usually lasts from 6 to 8 hours and may reach up to 24 hours. Its analgesic power can be up to five to 10 times higher than morphine. Its oral absorption is quick and almost complete, and its metabolism occurs mainly in the liver. Methadone and its metabolites can be eliminated by feces and urine. Renal excretion of methadone decreases with time of use and can, therefore, be used in patients with chronic kidney disease. It causes less nausea, constipation and sedation than morphine. However, the interaction between methadone and other drugs is more frequent than with morphine ${ }^{14,40}$.

\section{Buprenorphine}

The buprenorphine is a thebaine derivative, 25 to 40 times more potent than morphine. Its action mechanism is suggested to occur by partial agonist effects on MOP and KOP, as well as antagonistic action on DOP. It is found in intravenous, sublingual and transdermal presentations, the latter being the only one available in Brazil. The patches come in the 5, 10 and 20 $\mu \mathrm{g} / \mathrm{h}$ presentations, which are released within seven days. It has no systemic accumulation and its elimination occurs mainly through the intestinal tract and is therefore considered safe in patients with renal failure ${ }^{6}$.

\section{FINAL CONSIDERATIONS}

Considering the main strong opioids described, it is noteworthy that pain intensity is not adequately assessed in approximately $50 \%$ of cancer patients. Besides, adverse effects of opioids, such as nausea, vomiting and constipation, may be limiting factors for the use of these drugs, leading to their early discontinuation and consequent inadequate analgesic efficacy. Therefore, in order to achieve proper pain management in cancer patients, it is necessary to simultaneously minimize both the pain and the adverse effects of opioids employed for its control ${ }^{12,36,39,40}$.

It is essential that health professionals assess the barriers that prevent or hinder the use of opioids in the elderly when treating cancer pain. In several situations, these patients are undertreated due to the lack of knowledge about cancer pain management, due to their pain complaints not being adequately taken into account, due to the fear of the complications arising from the use of opioids and due to bureaucratic and cultural difficulties in the implementation of this type of pharmacological therapy.

Some points are important to elucidate the difficulties in prescribing opioids when treating cancer pain, such as inadequate pain assessment, as only a small number of physicians reported applying pain management guidelines in their practice; 23 to $31 \%$ of physicians tend to delay the adoption of strong opioids until patients reach the terminal stage of their disease, or until their pain becomes intractable due to the difficulty in managing adverse effects; 25 to $40 \%$ of physicians are concerned about opioid addiction, and there is even greater fear in patients with a family history of addiction. Moreover, although oncologists have shown excellent basic knowledge about the use of opioids to treat cancer pain than physicians in other specialties, there is still a significant information deficit within their specialty ${ }^{15,24,27,37,39,41}$.

From the patient's perspective, other potential barriers to the use of opioids may include lack of communication with 
physicians, resulting in insufficient notification of symptoms; misconceptions about the pain drug due to the fear of adverse effects, dependence, tolerance, and reduced immunity; and fatalistic beliefs, i.e., if the pain is increasing, the idea of inevitable and uncontrollable progression of the disease is created. Patients with drug concerns and misconceptions have worse adherence to treatment. In addition, pain intensity is associated with a higher level of psychological distress, including depression, anxiety, hostility, and mood disorders. Therefore, there is a need for psychiatric and psychological follow-up to complement and increase the efficiency of pharmacological treatment ${ }^{10,13,22,23}$.

Also, bureaucratic difficulties imposed on the prescription by government agencies, as well as on the access to these drugs and their price, were reported. Regulatory restrictions on opioid prescribing differ widely across countries. Thus, in developed countries, physicians have access to a wide range of opioids, while those in developing countries have limited treatment options $s^{20-22}$.

In order to solve or alleviate these problems mentioned above, there are several strategies, including the use of validated pain scales for patient pain selection and monitoring; multicomorbidities assessment; multidimensional assessment; choice of opioids according to the particularities and pathophysiology of pain; anticipation and treatment of adverse effects; referral to other specialties when necessary; education of patients, families and, especially, caregivers; provision of psychosocial support; information to patients that most cancer pain can be alleviated; establish realistic and objective expectations regarding pain. In addition to this, it is necessary to promote educational lectures to disseminate strategies to be adopted for better pain management by health professionals and to increase the availability of opioids.

\section{CONCLUSION}

The results showed that opioids remain the pillar in cancer pain treatment in the elderly. They can be used for better pain management, but with caution due to the possible adverse effects. In addition, pain management in the elderly requires a multifactorial analysis, including comorbidities, polypharmacy, and patient functionality. Therefore, it is necessary to treat the elderly patient individually in order to maximize results, reduce adverse effects and improve quality of life.

\section{REFERENCES}

1. United Nations. World population prospects: the 2017 revision, key findings and advance tables. Working Paper No. ESA/P/WP/248. New York: UN Department of Economic and Social Affairs, Population Division; 2017. Disponível em: https://esa. un.org/unpd/wpp/Publications/Files/WPP2017_KeyFindings.pdf.

2. Figueiredo $\mathrm{AH}$ (Org.) Brasil: uma visão geográfica e ambiental no início do século XXI. Rio de Janeiro: IBGE, Coordenação de Geografia; 2016. Disponível em: https:// biblioteca.ibge.gov.br/visualizacao/livros/liv97884.pdf.

3. Miranda GM, Mendes AC, Silva AL. O envelhecimento populacional brasileiro: desafios e consequências sociais atuais e futuras. Rev Bras Geriatr Gerontol. 2016;19(3):507-19

4. Estapé T. Cancer in the elderly: challenges and barriers. Asia Pac J Oncol Nurs. 2018;5(1):40-2.

5. Rangel O, Telles C. Tratamento da dor oncológica em cuidados paliativos. Rev Hosp Universit Pedro Ernesto. 2012;11:32-7.
6. Reyes-Gibby CC, Anderson KO, Todd KH. Risk for opioid misuse among emergency department cancer patients. Acad Emerg Med. 2016;23(2):151-8.

7. Yen TY, Chiou JF, Chiang WY, Su WH, Huang MY, Hu MH, et al. Proportional dose of rapid-onset opioid in breakthrough cancer pain management: An open-label, multicenter study. Medicine. 2018;97(30):e11593.

8. Paice JA, Ferrell B. The management of cancer pain. CA Cancer J Clin. 2011;61(3):157-82.

9. World Health Organization. Cancer pain relief. WHO: Geneva; 1986

10. Coluzzi F, Taylor R Jr, Pergolizzi JV Jr, Mattia C, Raffa RB. [Good clinical practice guide for opioids in pain management: the three $\mathrm{Ts}$ - titration (trial), tweaking (tailoring), transition (tapering)]. Rev Bras Anestesiol. 2016;66(3):310-7. Portuguese, English.

11. Wilson KG, Chochinov HM, Allard P, Chary S, Gagnon PR, Macmillan K, et al. Prevalence and correlates of pain in the Canadian National Palliative Care Survey. Pain Res Manag. 2009;14(5):365-70.

12. Galicia-Castillo M. Opioids for persistent pain in older adults. Cleve Clin J Med. 2016;83(6):443-51

13. Passik SD. Issues in long-term opioid therapy: unmet needs, risks, and solutions. Mayo Clin Proc. 2009;84(7):593-601.

14. Hennemann-Krause L. Aspectos práticos da prescrição de analgésicos na dor do câncer. Rev Hosp Universit Pedro Ernesto. 2012;11:38-49

15. Madadi P, Hildebrandt D, Lauwers AE, Koren G. Characteristics of opioid-users whose death was related to opioid-toxicity: a population-based study in Ontario, Canada. PLoS One. 2013;8(4):e60600.

16. Srisawang P, Harun-Or-Rashid M, Hirosawa T, Sakamoto J. Knowledge, attitudes and barriers of physicians, policy makers/regulators regarding use of opioids for cancer pain management in Thailand. Nagoya J Med Sci. 2013;75:201-12.

17. Zeppetella G. Fentanyl sublingual spray for breakthrough pain in cancer patients. Pain Ther. 2013;2(1):1-9.

18. Kraychete DC, Siqueira JT, Garcia JB. Recommendations for the use of opioids in Brazil: Part II. Use in children and the elderly. Rev Dor. 2014;15(Suppl 1):S65-9.

19. Nunes BC, Garcia JB, Sakata RK. [Morphine as first medication for treatment of cancer pain]. Braz J Anestesiol. 2014;64(4):236-40. Portuguese. English.

20. Rocha LS, Beuter M, Neves ET, Leite MT, Brondani MC, Perlini NM. Self-care of elderly cancer patients undergoing outpatient treatment. Texto Contexto Enferm. 2014;23(1):29-37.

21. Kim YC, Ahn JS, Calimag MM, Chao TC, Ho KY, Tho LM, et al. Current practices in cancer pain management in Asia: a survey of patients and physicians across 10 countries. Cancer Med. 2015;4(8):1196-204.

22. Reticena KO, Beuter M, Sales CA. Vivências de idosos com a dor oncológica: abordagem compreensiva existencial. Rev Esc Enferm USP. 2015;49(3):419-25.

23. Cella IF, Trindade LCT, Sanvido LV, Skare TL. Prevalence of opiophobia in cancer pain treatment. Rev Dor. 2016;17(4):245-7.

24. Lin $\mathrm{CP}, \mathrm{Hsu} \mathrm{CH}, \mathrm{Fu}$ WM, Chen HM, Lee YH, Lai MS, et al. Key opioid prescription concerns in cancer patients: a nationwide study. Acta Anaesthesiol Taiwan. 2016;54(2):51-6.

25. Oosten AW, Abrantes JA, Jönsson S, De Bruijn P, Kuip EJM, Falcão A, et al. Treatment with subcutaneous and transdermal fentanyl: Results from a population pharmacokinetic study in cancer patients. Eur J Clin Pharmacol. 2016;72(4):459-67.

26. Reddy A, Tayjasanant S, Haider A, Heung Y, Wu J, Liu D, et al. The opioid rotation ratio of strong opioids to transdermal fentanyl in cancer patients. Cancer. 2016;122(1):149-56

27. Barbera L, Sutradhar R, Chu A, Seow H, Howell D, Earle CC, et al. Opioid prescribing among cancer and non-cancer patients: Time trend analysis in the elderly using administrative data. J Pain Symptom Manage. 2017;54(4):484-92.e1.

28. Bennett M, Paice JA, Wallace M. Pain and opioids in cancer care: benefits, risks, and alternatives. Am Soc Clin Oncol Educ Book. 2017;37:705-13

29. Haider A, Zhukovsky DS, Meng YC, Baidoo J, Tanco KC, Stewart HA, et al. Opioid prescription trends among patients with cancer referred to outpatient palliative care over a 6-year period. J Oncol Pract. 2017;13(12):e972-81.

30. Kuip EJ, Zandvliet ML, Koolen SL, Mathijssen RH, van der Rijt CC. A review of factors explaining variability in fentanyl pharmacokinetics; focus on implications for cancer patients. Br J Clin Pharmacol. 2017;83:294-313.

31. Lee KH, Kim TW, Kang JH, Kim JS, Ahn JS, Kim SY, et al. Efficacy and safety of controlled-release oxycodone/naloxone versus controlled-release oxycodone in Korean patients with cancer-related pain: a randomized controlled trial. Clin J Cancer2017;36(1):74

32. Nosek K, Leppert W, Nosek H, Wordliczek J, Onichimowski D. A comparison of oral controlled-release morphine and oxycodone with transdermal formulations of buprenorphine and fentanyl in the treatment of severe pain in cancer patients. Drug Des Devel Ther. 2017;11:2409-19.

33. Schmidt-Hansen M, Bennett MI, Arnold S, Bromham N, Hilgart JS. Oxycodone for cancer-related pain. Cochrane Database Syst Rev. 2017;8:CD003870.

34. Guitart J, Vargas MI, De Sanctis V, Folch J, Salazar R, Fuentes J, et al. Efficacy and safety of sublingual fentanyl tablets in breakthrough cancer pain management according to cancer stage and background opioid medication. Drugs R D. 2018;18(2):119-28.

35. Masel EK, Landthaler R, Gneist M, Watzke HH. Fentanyl buccal tablet for breakthrough cancer pain in clinical practice: results of the non-interventional prospective study ErkentNIS. Support Care Cancer. 2018;26(2):491-7.

36. Peng Z, Zhang Y, Guo J, Guo X, Feng Z. Patient-controlled intravenous analgesia 
for advanced cancer patients with pain: A retrospective series study. Pain Res Manag. 2018;2018.7323581.

37. Yamada M, Matsumura C, Jimaru Y, Ueno R, Takahashi K, Yano Y. Effect of continuous pharmacist interventions on pain control and side effect management in outpatients with cancer receiving opioid treatments. Biol Pharm Bull. 2018;41(6):858-63.

38. Sociedade Brasileira de Geriatria e Gerontologia. Dor: o quinto sinal vital - Abordagem prática no idoso. Rio de Janeiro: Sociedade Brasileira de Geriatria e Gerontologia, 2018. Disponível em: <http://www.amape.com.br/wp-content/uploads/2018/06/ SBGG_guia-dor-no-idoso_2018-digital.pdf>.
39. Kim HJ, Kim YS, Park SH. Opioid rotation versus combination for cancer patients with chronic uncontrolled pain: a randomized study. BMC Palliat Care. 2015;14(1):41.

40. Ribeiro S, Schmidt AP, Schmidt SR. [Opioids for treatment non-malignant chronic pain: the role of methadone]. Rev Bras Anestesiol. 2002;52(5):644-51. Portuguese, English.

41. Nguyen LMT, Rhondali W, De La Cruz M, Hui D, Palmer L, Kang DH, et al. Frequency and predictors of patient deviation from prescribed opioids and barriers to opioid pain management in patients with advanced cancer. J Pain Symptom Manage. 2013;45(3):506-16. 